\title{
PREPAREDNESS TO TEACH INTERNATIONAL FINANCIAL REPORTING STANDARDS (IFRS) IN ETHIOPIA: A STUDY ON SELECTED UNIVERSITIES
}

\author{
Deresse Mersha Lakew \\ Jimma University, Jimma, Ethiopia \\ deresmersha@gmail.com \\ Mohammed Getahun Musa \\ Jimma University, Jimma, Ethiopia \\ mamegetahun@gmail.com
}

\begin{abstract}
Modern type of business organizations was started in Ethiopian before hundred years ago and the number is tremendously increasing nowadays. However, there was no one set of generally accepted accounting standard used by business organization in the country till December 2014 when IFRS was proclaimed as the law of the land. Though IFRS was accepted for financial reporting in the country starting from 2014, the level of preparedness in teaching IFRS in Ethiopian universities was not studied. This paper is aimed at identifying problems in teaching IFRS among teachers in Ethiopia universities. To achieve this objective, data was collected from 46 academic staffs working in six universities in the country. The study found that teachers in relatively old universities are trying to incorporate IFRS in their course plan as compared to those in recently established universities. Generally, the level of preparedness to incorporate IFRS is low in majority of the universities under study. Lack of text books in line with IFRS, problem of integrating IFRS in to the curriculum and lack of practical experiences are the top three bottle necks that hinder teaching IFRS in our universities. In order to prepare our staffs to teach in line with IFRS, both short and long term capacity building strategies were recommended in this study.

Keywords: International Financial Reporting Standard, Preparedness, Universities, Ethiopia.
\end{abstract}

\section{INTRODUCTION}

Education is the backbone for the development of any nation. It is because of this that Ethiopian government is investing a huge amount of resource on expansion of schools and universities throughout the country. Many universities came to existence within a few years to increase the accessibility of higher education to citizens capable of perusing their training at tertiary level. Accounting and Finance is one of the departments that we find in most universities in the country. The department is responsible 
to prepare students for the rewards and challenges facing them in the professional accounting, finance and auditing world both today and tomorrow.

However, opening many universities and departments by itself may not bring the required result. It has to be equipped with the necessary skilled manpower, teaching material and other pertinent facilities. Education cannot play its role unless it is of the highest quality and is relevant to the development needs of the country. In order to equip students with the necessary skills and knowledge's, there must be adequate manpower and teaching facilities. The library should be equipped with relevant and up-to-date books. The curriculum should be designed in line with development needs of the country and the contents incorporated in the courses should be up-to-date with the current development in the globe.

International Financial Reporting Standards, commonly referred to as IFRS, is gaining acceptance as the global norm in financial reporting. Issued by International Accounting Standards Board (IASB), IFRS is currently accepted in more than 144 countries in the world (IASB, 2019). In line with this, as of December 2014, Ethiopian parliament has proclaimed companies, public enterprises and small and medium enterprises in the country should prepare their financial report in line with the international accepted IFRS. Accounting and Auditing Board of Ethiopia (AABE) was also established to facilitate the adoption of IFRS and control Accounting and auditing profession in the country (Proclamation No.847/2014). So, it is important that today's accounting students have a basic understanding of these standards as they are responsible for preparing financial report in line with IFRS tomorrow, when they complete their study. The purpose of this study is to assess the level of preparedness of accounting and finance teachers in incorporating IFRS in their course and session plan.

\section{STATEMENT OF THE PROBLEM}

Although Ethiopia was never been colonized, it's economic and social environments were significantly shaped by its dependence on Western countries for resources. When one closely looks at accounting profession in the country, it is characterized as importing accounting education from one source and accounting practice from another source. Accounting education in Ethiopia was introduced by US academics and was modeled based on the US accounting education system. As a result, universities were teaching accounting principles and theories which are formulated based on US accounting standards. Most of the accounting academic staffs we have today throughout the country are the products of this education system. On the other hand, British experts were the first to open public accounting practices; and the first Ethiopian professional accountants obtained British accounting qualification. Both trends continue to the present day. The sourcing of accounting education and 
accounting practice from different countries has led to the misalignment of the two and has adversely affected the development of the profession and restricted its contributions to the economic development of the country (Mihret \& Bobe ,2014).

To solve this misalignment of accounting education and practice in the country, the House of Peoples Representatives (HPR) adopted International Financial Reporting standards (IFRS) with the aim of unifying the country's finance and audit standards. A Board was also established to implement a unified reporting standard across the country and comply with the standards acceptable at international level. Therefore, Students of today need to be prepared for what they will face outside of academia in their careers as the conversion to IFRS is certain in the country's financial reporting. Coursework needs to be adapted to ensure that students are exposed to all the knowledge, skill and attitude they need to succeed and that they are able to communicate, analyze and utilize financial information. Today's student must be made aware of IFRS, its principles, and its impact on the accounting world. The future accountants must prepare themselves and become fluent in IFRS.

However, the most difficult tasks for instructors are finding and assimilating all resources available, developing a curriculum that works in their classrooms, and educating themselves in all of the potential changes as convergence continues. In most universities, many instructors are having difficulty discerning the how, when, and what of incorporating IFRS into today's accounting courses as most of them have limited practical experience. All universities are using common harmonized curriculum which is not well integrated with IFRS. Though there is an effort to train accounting and finance teachers to enable them integrate IFRS in their daily lesson, there are no studies that investigated to what extent they are trying to incorporate IFRS in their course plan. Therefore, the main objective of this study is to identify the challenges while incorporating IFRS in the accounting and finance program. Specifically, the study is aimed to:

1. Investigates the level of preparedness of academic staffs in teaching IFRS at selected universities in Ethiopia

2. Identify the main challenges while incorporating IFRS in to the curriculum and course plan

\section{LITERATURE REVIEW}

International financial reporting standard (IFRS) is a set of accounting standard prepared by the London based standard setting body named "International Accounting Standard Board (IASB)" and its earlier forerunner International Accounting Standards Committee (IASC). The need for IFRS arise as a result of the desire of multinational companies for one set of financial statements, and the demand for one 
common global reporting language. According to IASB (2019) report, currently about 144 countries have decided to adopt IFRS and other 12 countries permits IFRS. Ethiopia is one of the countries that proclaimed to adopt IFRS in December 2014. By July 8, 2020, all private and public reporting business enterprises in the country are required to prepare their financial statement in line with IFRS (Proclamation No. 847/2014).

The application of global standards including IFRS requires a high level of human capacity that can be developed through education, training and experience. In order to achieve the above framework, adequate number of competent accounting and auditing professionals should be produced. For this purpose, curriculum in accounting and finance education at higher institutions should be integrated with IFRS or include modules in IFRS to narrow the gap between what is taught at the universities and what is required in the work place to provide fast track entry for professional qualification for graduates (AABE, 2015; UNCTAD, 2013).

However, previous studies showed that there are a number of human capacity related challenges that countries face when implementing IFRS and other standards developed at international level. These challenges occur to a varying extent in all countries regardless of their level of economic development. Changing in to a new accounting standard is challenging and a critical integral component in such a transition period is developing the necessary competencies of human resource Thus, developing human resource capacity for corporate reporting in a sustainable manner requires regulatory and institutional support as well as reliable sources of funding (UNCTAD, 2013).

Poor IFRS education is one of the major bottlenecks for successful IFRS implementation identified by IASB (2019). The adoption of IFRS for accounting education are considered important due to the role played by accounting educators in providing graduates for the business world globally. Some of the factors affecting IFRS adoption for educators around the world have been addressed in the literature. For example, the lack of accounting educators with experience in IFRS, the lack of textbooks and educational materials in languages other than English , and the broader range of skills that need to be addressed in accounting curriculum, academics' resistance to changing the way they teach, Environment in which the change is to occur, budget constraints associated with the change, time investment required from academics to support the change, academics' dependency on textbooks and ready materials to avoid extra preparation for lectures, academics' lack of updated knowledge on emerging issues and lack of interdisciplinary knowledge are some of the factors hindering incorporation of IFRS in the accounting curriculum and the main causes resulting in increasing the hesitation of accounting academics to start teaching IFRS (Albader, 2014; Saito et al., 2013; Vysotskoya \& Prokfeiva, 2013). 
In transitioning to IFRS, there is an understanding that IFRS requires the exercise of professional judgment involving a high level of professional experience. Hence, while teaching Principle based IFRS, teachers should design instructional methods that require them to be active, independent learners and problem solvers rather than passive recipients of information in the class room. A student centered approach represents the most modern approach of teaching principle - based standards such as IFRS. The benefits of this approach stems from its focus on the development of students' critical - thinking and professional - judgment skills. This approach assists in increasing students' conceptual understanding of economic events, accounting concepts and principle. Thus, teachers should utilize new teaching methods that are more relevant to a principle - based approach such as simulations, role plays, oral presentations by students and problem - based case studies with multiple solutions (Albader, 2014).

However, this method has its own challenges both for the teachers and students. Accounting academics have the challenges of preparing questions and cases for examinations and evaluating and grading students' responses (Bonnier et al., 2013). Conversely, students face the challenge of studying and preparing for examinations, ensuring that they cover all required aspects of what constitutes a correct and appropriate answer. Students also need to be sure of the accuracy and fairness of the grading process (Bonnier et al., 2013). Similarly, Tan, Chatterjee and Bolt, (2013) attribute difficulties in adopting a principle - based approach of teaching accounting to the tendency of students and academics towards rule-based approach that favors a system of teaching and learning in which 'right' and 'wrong' are easily identified. They added that accounting academics need to compromise the ease of preparing examinations and the grading process under the old approach with the benefits of applying new pedagogical approaches despite the difficulties and challenges associated with these new approaches. Smaller class size has positive effects on students' grades and performance. Conversely, large class sizes are considered major impediments to students developing soft and generic skills and increasing the quality of teaching and the adoption of innovative pedagogical approaches.

Considering the principles -based nature of IFRS, which requires meeting the learning outcomes of developing critical thinking and exercising judgment, most studies encouraged an active learning approach to teaching IFRS. Active learning engages students in higher order thinking, exercising their critical thinking skills, and requires teachers to focus on what students do, rather than on transmission of information (Tan, Chatterjee and Bolt, 2013).

\section{RESEARCH METHODOLOGY}

The research design adopted in this study is descriptive in nature. This is because the objective of the study is to examine the level of preparedness of academic staffs to teach IFRS and the associated 
challenges. The data for the study was collected mainly from selected public and private universities in the country. There are about 43 public universities and many more private universities and college that are training students in accounting and finance discipline in either regular or continuing and distance education program at the moment. It is very difficult to incorporate the whole universities and colleges in the study since they are very much dispersed throughout the country. Hence, multi stage sampling methods was employed to select representative universities. First universities in central and west Ethiopia were selected for convenience of data collection. Second, the universities in the central and western Ethiopia were categorized in to four generations and six universities were selected for this study. Therefore, two sample universities were selected from first, second and third generation universities respectively. Fourth generation universities were not included in this study since they are still at establishment stage. Finally, from each of the six universities, 10 academic staffs were selected for questionnaire which gives a total sample of 60 academic staffs. The following table 1 shows the selected universities, selected sample respondents and actual respondents from each university.

TABLE 1: SELECTED UNIVERSITIES FOR THE STUDY

\begin{tabular}{|c|c|c|c|c|}
\hline Sample Universities & $\begin{array}{l}\text { Ownership of the } \\
\text { Universities }\end{array}$ & $\begin{array}{l}\text { Sample } \\
\text { Respondents }\end{array}$ & $\begin{array}{l}\text { Actually } \\
\text { Respondents }\end{array}$ & $\begin{array}{l}\text { Response rate } \\
(\%)\end{array}$ \\
\hline Addis Ababa & Public & 10 & 10 & 100 \\
\hline Jimma University & Public & 10 & 8 & 80 \\
\hline Mizan Tepi University & Public & 10 & 8 & 80 \\
\hline Rift valley university & Private & 10 & 3 & 30 \\
\hline Wolkite University & Public & 10 & 9 & 90 \\
\hline Mettu University & Public & 10 & 8 & 80 \\
\hline Total & & 60 & 46 & 76.67 \\
\hline
\end{tabular}

Source: Authors' computations

The low response rate at Rift Valley University is because; most of the teachers are par timer working in a nearby public university. To facilitate the analyses, the study used different methods of data collection including survey questionnaire and Interview with department heads. Questionnaires were personally distributed to accounting and finance teachers in each university. Further, semi structured interview was made with accounting and finance department heads in each universities in order to triangulate the data obtained through questionnaire.

\section{RESULT AND DISCUSSION}

Before going to the discussion of the main objectives of the study, it is important to know the characteristics of academic staffs contacted. Ten academic staffs from each university teaching accounting and finance courses at undergraduate level were selected for the study and survey 
questionnaire was given to them. However, only forty-six completed questionnaires were returned back. The demographic characteristics of the respondents are summarized in table 2 below.

TABLE 2: DESCRIPTION OF THE RESPONDENTS

\begin{tabular}{|c|c|c|c|}
\hline Educational Level & $\%$ & Specialization & $\%$ \\
\hline - Ph.D. & $6.52 \%$ & - Accounting and Finance & $84.78 \%$ \\
\hline - Masters & $80.43 \%$ & - MCom (Accounting) & $6.52 \%$ \\
\hline - BA Degree & $13.04 \%$ & - Finance and Investment & $6.52 \%$ \\
\hline Age & $\%$ & Experience & $\%$ \\
\hline - Less than 25 Years & $17.39 \%$ & - 0 - 5 Years & $39.13 \%$ \\
\hline - $26-35$ Years & $63.04 \%$ & - $6-10$ Years & $32.61 \%$ \\
\hline - Greater than 35 Years & $19.57 \%$ & - Greater than 10 Years & $28.26 \%$ \\
\hline Sex & $\%$ & Marital Status & $\%$ \\
\hline - Male & $82.61 \%$ & - Single & $47.83 \%$ \\
\hline - Female & $17.39 \%$ & - Married & $60.87 \%$ \\
\hline
\end{tabular}

Source: Authors' computations

From Table 2 above, it can be seen that the majority of the respondents have master's degree and above education level in accounting and finance discipline. This indicates that the academia involved in teaching accounting and finance are relatively well trained as compared to the past situation in the country. With respect to age, the majorities are below 35 years with less than ten years of experience which implies majority of the teachers are in their young age categories who are less resistance to changes coming. Further, the majorities of the academic staffs are males and married which implies the dominance of male in the accounting and finance academic staffs.

IFRS become the law of the land starting from December 2014. Hence, students of today should be trained in line with IFRS and accounting and finance programs at university should incorporate IFRS in the curriculum and academicians should be prepared to teach IFRS. In connection to this, academic staffs teaching accounting and finance courses at undergraduate level were asked to state their experience of incorporating IFRS in to their daily session plan. The result is summarized in table 3 below

TABLE 3: PRACTICE OF TEACHING IFRS

\begin{tabular}{lll}
$\begin{array}{l}\text { Have you started teaching IFRS whenever you are } \\
\text { assigned to related courses? }\end{array}$ & Frequency & $\%$ \\
\hline Yes all the times & 11 & $23.91 \%$ \\
Yes sometimes & 20 & $43.48 \%$ \\
Not at all & 12 & $26.09 \%$ \\
\hline Total & 46 & $100 \%$ \\
\hline
\end{tabular}

Source: Authors' computations 
Table 3 above shows that only about $24 \%$ of the respondents are incorporating IFRS in their daily session plan all the times. About $43.50 \%$ of the respondents are including IFRS only sometimes and about $26 \%$ of the academics did not incorporate in to their daily session plan at all. This implies majority of the teachers are not adopting IFRS consistently in their courses as a result of low preparedness. In relation to this, existing studies highlighted that several institutional factors can influence what is included in the accounting curriculum. Further, characteristics of academic staffs, such as their background, have been shown to play a significant role in the development of course content. Chi square test was used to see the association between the different demographic variables and the practice of teaching IFRS in the class. The result was summarized in the table 4 below.

TABLE 4: ASSOCIATION BETWEEN TEACHING IFRS AND SELECTED VARIABLES

\begin{tabular}{|c|c|c|c|c|c|c|}
\hline & \multicolumn{3}{|c|}{ Teaching IFRS } & \multirow[t]{2}{*}{ Total } & \multirow[t]{2}{*}{$\mathrm{X}^{2}$ Test } \\
\hline & & Always & Sometimes & Not at all & & \\
\hline \multirow{3}{*}{$\begin{array}{l}\text { Generation } \\
\text { of university }\end{array}$} & First & 10 & 7 & 3 & 20 & $x^{2}=15.452$ \\
\hline & n Second & 0 & 3 & 5 & 8 & Asymp. Sig $=0.004$ \\
\hline & ity Third & 1 & 10 & 7 & 18 & \\
\hline \multirow[t]{3}{*}{ Total } & & 11 & 20 & 15 & 46 & \\
\hline & & \multicolumn{3}{|c|}{ Teaching IFRS } & \multirow{2}{*}{ Total } & \\
\hline & & Always & Sometimes & Not at all & & \\
\hline \multirow{3}{*}{$\begin{array}{l}\text { Education } \\
\text { Level }\end{array}$} & Ph.D. & 1 & 2 & 0 & 3 & $X^{2}=4.725$ \\
\hline & Masters & 10 & 15 & 11 & 36 & Asymp. Sig $=0.317$ \\
\hline & BA & 0 & 3 & 4 & 7 & \\
\hline \multirow[t]{3}{*}{ Total } & & 11 & 20 & 15 & 46 & \\
\hline & & \multicolumn{3}{|c|}{ Teaching IFRS } & \multirow[t]{2}{*}{ Total } & \\
\hline & & Always & Sometimes & Not at all & & \\
\hline \multirow{3}{*}{$\begin{array}{l}\text { Experien } \\
\mathrm{ce}\end{array}$} & $>10$ Years & 7 & 4 & 0 & 11 & $x^{2}=16.832$ \\
\hline & $6-10$ years & 3 & 10 & 6 & 19 & Asymp. Sig $=0.002$ \\
\hline & $\leq 5$ Years & 1 & 6 & 9 & 16 & \\
\hline \multirow[t]{3}{*}{ Total } & & 11 & 20 & 15 & 46 & \\
\hline & & \multicolumn{3}{|c|}{ Teaching IFRS } & \multirow[t]{2}{*}{ Total } & \\
\hline & & Always & Sometimes & Not at all & & \\
\hline \multirow{3}{*}{ Age } & $>35$ Years & 7 & 3 & 0 & 10 & $x^{2}=17.064$ \\
\hline & $26-35$ years & 4 & 12 & 10 & 26 & Asymp. Sig $=0.002$ \\
\hline & $\leq 25$ Years & 0 & 5 & 5 & 10 & \\
\hline \multirow[t]{3}{*}{ Total } & & 11 & 20 & 15 & 46 & \\
\hline & & \multicolumn{3}{|c|}{ Teaching IFRS } & \multirow[t]{2}{*}{ Total } & \\
\hline & & Always & Sometimes & Not at all & & \\
\hline \multirow{2}{*}{ Sex } & Female & 0 & 3 & 4 & 7 & $X^{2}=4.725$ \\
\hline & Male & 11 & 17 & 11 & 39 & Asymp. Sig $=0.174$ \\
\hline Total & & 11 & 20 & 15 & 46 & \\
\hline
\end{tabular}

From table 4 above, one can see that teaching IFRS is significantly associated with the age of the universities identified by generation, experience and age of the academia. This implies, academic staffs working in first and second generation universities tend to teach IFRS more as compared to those in third generation universities. This might be because old universities have well established facilities 
including libraries and internet connection where one can easily find IFRS related resources. This finding is in line with the finding of Groomer and Murthy (1996) who identified several institutional factors that affect the course content of Accounting subjects including the size of university, type of university, number of academic staffs, and whether the institution is a doctoral granting school or not.

In addition, the $\chi^{2}$ test further shows relatively older teachers with long years of experience tend to teach IFRS as compared to relatively young teachers with short years of experience. This is in line with Watson et al. (2007) who suggested that professional experience including teaching experience, research interest, and training have direct impact on course delivery methods and ultimately affect the skills and knowledge of the students. However, education level and gender has no significant association with the practice of teaching IFRS. Teachers under the study were asked to identify the main challenges while incorporating IFRS in their course plan and the result is summarized in the figure 1 below.

\section{FIGURE 2: CHALLENGES IN TEACHING IFRS}

Source: Authors' computations

Figure 1 above shows large majority of teachers surveyed identified lack of text books in line with IFRS, problem of integrating IFRS in to the curriculum and lack of industry Experiences are the top three bottle necks that hinder teaching IFRS in the class. Developing 'new' materials and getting textbook authors/publishers to incorporate IFRS material is seen as a problem in developing country like ours. On the date of awareness creation workshop conducted by Accounting and Auditing Board of Ethiopia (AABE) back in 2016, representative of the Board recommended the design and implementation of a national curriculum that can meet the international standards in the field of study. Furthermore, the Board also promised to work closely with universities and colleges to help them revamp their curriculum so that they can teach their students with materials which are up to the standards and the international 
practices of the field. However, the curriculum revision was not finalized till to date and it is still the major bottleneck raised by department heads in each university.

The other challenges cited by teachers and department heads includes Lack of adequate training in IFRS. Intensive training of academic staffs plays critical role in teaching IFRS as the majority of the staffs are educated using US based accounting system. Interview with the six department heads shows that four out of the six department heads have organized short term training to their staffs. One university is planning to do so in the near future and the remaining one is a private university and has no plan to train as most the teachers are par timers. In this respect, most department heads responded that arranging training on IFRs has taken long time because of administrative and budget challenges and the training provided by itself was not intensive and complete because of lack of qualified trainers in the country. Confusion of teaching two types of standards; absence of incentives and time shortage to do so; Lack of staff motivation and use of common harmonized curriculum are additional challenges mentioned by respondents.

Incorporating principle based IFRS in course plan while teaching accounting and finance subjects is becoming problematic. This is because most of the text books used in the currently working curriculum are written based on US GAAPs. This implies revision of the existing curriculum is the first requirement. Department heads in each university complain that curriculum revision was started before three years under the responsibility of Addis Ababa University but not completed yet because of administrative and financial limitations. In connection to this, academicians have different opinion on how to include IFRS in the curriculum. Those teachers who are teaching IFRS either always or some times were asked their preference in incorporating IFRS in the accounting and finance curriculum and the result is summarized in table 5 below.

TABLE 5: METHODS OF INCORPORATING IFRS IN THE ACCOUNTING AND FINANCE CURRICULUM

\begin{tabular}{|c|c|c|c|}
\hline $\begin{array}{l}\text { What do you suggest on how to } \\
\text { inculcate IFRs in to } \\
\text { undergraduate Accounting and } \\
\text { finance curriculum }\end{array}$ & $\%$ & $\begin{array}{l}\text { If you suggest integration to other courses, } \\
\text { in to which of the following course should it } \\
\text { be integrated? }\end{array}$ & $\%$ \\
\hline - Separate IFRS Module & $23.91 \%$ & - Financial Accounting & $78.26 \%$ \\
\hline $\begin{array}{l}\text { - Integrating to other } \\
\text { courses }\end{array}$ & $60.87 \%$ & - Principles of Accounting & $76.09 \%$ \\
\hline \multirow[t]{5}{*}{ - Both together } & $21.74 \%$ & - Advanced Financial Accounting & $60.87 \%$ \\
\hline & & - Cost and Management Accounting & $36.96 \%$ \\
\hline & & - Accounting Information systems & $36.96 \%$ \\
\hline & & - Government and NFP accounting & $36.96 \%$ \\
\hline & & - Public Finance and Taxation & $30.43 \%$ \\
\hline
\end{tabular}


Table 5 above shows that majority of the academics have the opinion that IFRS should be integrated in to other courses. This is in line with Berrios (2012), who suggested the integrated approach to IFRS education rather than teaching IFRS as a separate module in Latin America. The study by Judy et al. (2016) also support that the main approach to teaching should be to integrate IFRS into existing courses instead of a separate module. According to them, most integration should be done in to Intermediate or advanced accounting modules although other courses can also be used for integration. This is similar with the opinion of academic staffs in this study who suggested integration should be made to financial accounting, principles of accounting and advanced financial accounting courses.

Another important preparation while teaching IFRS is a change in method of teaching. Past literature has discussed different teaching methods applied to teach IFRS. Most studies suggested that real-life case studies are the best method to teach IFRS because IFRS are principles - based (Tan, Chatterjee \& Bolt, 2013). In connection to this, academic staffs were asked the method of teaching they are using at the moment in their class. The response was summarized in table 6 below.

TABLE 5: METHODS OF TEACHING USED AT THE MOMENT

\begin{tabular}{lrr}
\hline Methods of Teaching & Frequency & Percentage \\
\hline Lecture Method & 43 & $93.48 \%$ \\
Group work Method & 21 & $45.65 \%$ \\
Cooperative teaching method & 15 & $32.61 \%$ \\
Practical teaching method & 10 & $21.74 \%$ \\
Case based Teaching & 6 & $13.04 \%$ \\
\hline
\end{tabular}

Source: Authors' computations

As we can see from the table 6 above, lecture method is the most dominant method of teaching practiced by teachers. Group work, cooperative teaching, practical teaching and cased based teaching are next in respective order. This indicates that most accounting academics in Ethiopia tend to prefer traditional way of teaching, an approach not ideally suited to teaching IFRS. This implies an awareness of this issue is required to ensure there is an appropriate shift in direction of academics' teaching approaches so that accounting academics are prepared to teach principles - based IFRS. Most studies suggested that real- life case studies are the best method to teach IFRS because IFRS are principle based. The reason behind suggesting case studies is that they inform students about the real world, develop their critical thinking and familiarize them with companies' financial statements (Tan, Chatterjee \& Bolt, 2013). Department heads further indicated that most of the teachers in higher institution are not prepared for teaching profession and they did not take any pedagogy course. Hence, most of them are following traditional method of teaching as indicated above. 


\section{CONCLUSION AND RECOMMENDATION}

There is a gap between Ethiopia's accounting education system and the international standards of the profession. Since many international companies are now coming to Ethiopia we need to work hard to comply with the standards. One way we do that is starting with the accounting education system in order to meet the international standard in terms of accounting curriculum and daily session plan.

This study found that although the roadmap of adopting IFRS in the country specifically mandate to accept IFRS starting from 2015/16, university accounting and finance education is lagging behind in teaching future accountants about IFRS. Only limited number of academic staffs are exerting their personal effort to update themselves with recent development in accounting and finance and incorporate IFRS in their lesson. The major bottle necks identified includes absence of books written in line with IFRS, problem of integrating IFRS in to curriculum, Lack of industry experience, lack of training, confusion of teaching two types of standards, lack of incentives, time and motivation. The problems are critical in a recently opened new universities in the remote area in the country (third and fourth generation universities).

Mandatory adoption of IFRS in 2015/16 and the absence of a well-developed program for retraining of accountants to date indicate that much closer attention is needed to restructure the entire system of accounting and accounting education in the short and long time frame. Since the curriculum we are using at the moment was designed based on the US GAAP, the text books available in our library are US books. In addition, as IFRS is a resent development, it is very difficult to find text books written in line with it. Therefore, the researchers recommend that curriculum revision should be made urgently and books and other resources that are written in line with IFRS should be purchased by each universities. Universities should enable academic staffs to complete higher diploma program (HDP) that will help them change their method of teaching IFRS. Creating awareness by conducting term training and motivating academic staff to use resources written in line with IFRS are other suggested short term strategies to solve the problem.

In the long run, it is recommended that faculty members should have certificate of qualification in IFRS. Further, it is recommended employing academic staff who are certified accountants. The problem with this strategy is that it is difficult to obtain qualified staffs at the current university salary rate. Therefore, another possible strategy may be encouraging the existing academic staffs to pursue their training by covering the tuition fee at least partially.

Academic staffs should be encouraged to attend Higher diploma program (HDP) in pedagogy in order make them ready to teach IFRS. In addition, professional accounting bodies can play a vital role in helping universities revisit their pedagogical approaches, revise their accounting curricula and cope with 
the requirements of adoption of IFRS. For example, for a long time, the professional accounting organization in South Africa has greatly influenced the way accounting curricula are designed in South African universities. Therefore, strengthening accounting and auditing professional associations plays vital role in Ethiopia. Accounting and Auditing Board of Ethiopia should work hard in supporting professional associations in this respect.

\section{REFERENCES}

Albader M. (2014). Transition to IFRS and its Implications for Accounting Education in Saudi Arabia. (Ph.D. Thesis). Victoria University

Accounting and Auditing Board of Ethiopian (AABE) (2015). Five years strategic plan 2015/16 2020/21, Ethiopia, Addis Ababa

Bonnier, C, Demerens, F, Hossfeld, C \& Manh, A 2013, A French experience of an IFRS transition' Issues in Accounting Education , 28 (2) PP. 221234

Groomer, S. M., and Murthy U.S. (1996). An Empirical Analysis of the Accounting Information Systems Course. Journal of Information Systems, 10 (2), PP103-127.

IASB (2019) International Financial Reporting Standard (IFRS) accessed from https://www. ifrs.org/groups/international-accounting-standards-board/

Judy K. B., Michel M., Munter P. and Venuti E. (2016). Results of the AAA/KPMG Survey on Implementation of IFRS and Data Analytics into U.S. Accounting Curricula. Working paper, University of Rhode Island, College of Business Administration,

Mihret, D. G. and Bobe, B. J. (2014), Multiple informal imperial connections and the transfer of accountancy to Ethiopia (1905 to 2011), Accounting history, 19(2) PP. 309-331.

Proclamation 847/2014. A proclamation to provide for financial reporting. House of people's representative of federal government of Ethiopia, Addis Ababa

Saito H., Hiramatsu K., and Mayangosri S. (2013). Accounting Education for the Implementation of IFRS in Indonesia.

Vysotskoya A. \& Prokfeiva M. (2013). The difficulty of Teaching IFRS in Russia. Issues in Accounting Education. 23(1) PP. 309-319

Watson, S. F., Apostolou B, Hassell J.M., and Webber S.A. (2007). Accounting Education Literature

Review (2003-2005), Journal of Accounting Education 25 (2): PP. 1-58. 